\title{
THE MICRO ESTIMATION OF SERUM IRON AND IRON-BINDING CAPACITY IN NORMALS AND IN DISEASE
}

\author{
BY \\ G. DAVIES, B. LEVIN, AND V. G. OBERHOLZER \\ From the Department of Pathology, Queen Elizabeth Hospital for Children, London
}

(RECEIVED FOR PUBLICATION APRIL 2, 1952)

It is now well established that the transport of iron in plasma is by a specific iron-binding $\beta_{1}$ globulin component of the plasma protein which has been isolated (Schade and Caroline, 1946). Holmberg and Laurell (1945) concluded that the amount of iron in normal plasma by no means attains the limit of saturation of the specific ironbinding protein. This saturation limit has been termed by Laurell (1947) the iron-binding capacity of plasma, and he, as well as Rath and Finch (1949) and Cartwright and Wintrobe (1949), has shown that the simultaneous estimation of serum iron and iron-binding capacity, giving the percentage saturation, may be more informative than the simple determination of serum iron.

Apart from the thiocyanate method of Burch, Lowry, Bessey, and Berson (1948), which requires only $20 \mathrm{c} . \mathrm{mm}$. of serum, most methods for the estimation of serum iron require at least $1 \mathrm{ml}$. of serum. However, since this investigation was begun a method using a new colorimetric reagent for iron, o-tolidine, has been described (BudtzOlsen, 1951) requiring only $0.75 \mathrm{ml}$. serum for duplicate determinations. For the iron-binding capacity, only two methods have been described (Laurell, 1947 ; Cartwright and Wintrobe, 1949 ; Rath and Finch, 1949) and both require at least $2 \mathrm{ml}$. serum. In an investigation of serum iron and iron-binding capacity in infants and the newborn it was felt essential to devise a method suitable for the small amounts of blood which could be obtained by heel or finger prick rather than to limit the scope to those instances where adequate amounts could be obtained by venipuncture. From a review of the literature it appeared that the o-phenanthroline method of Heilmeyer and Plötner (1937), as modified by Laurell (1947), for both serum iron and ironbinding capacity could be most readily adapted as a micro-method. It possessed the advantage that fundamentally the same procedure was used for the two estimations, and that the presence of small amounts of haemoglobin did not introduce any appreciable error.

\section{Experimental}

In experiments requiring large amounts of serum these were obtained by venipuncture, observing the usual precautions to avoid contamination with iron. In all other estimations capillary blood from ear or finger was used. All glassware used for the collection of blood or in the analytical procedure was rendered iron-free as described below.

The use of $0.2 \mathrm{ml}$. amounts of serum instead of $6 \mathrm{ml}$. as in the original method of Laurell (1947) made it necessary to centrifuge the mixture after the precipitation of protein with trichloracetic acid instead of filtering. The supernatant must be clear, as even the slightest opalescence will, owing to the very faint colour developed, greatly increase the error of the Spekker reading. In the original method the filtrate obtained after removal of the protein with trichloracetic acid is neutralized, first with concentrated ammonium hydroxide solution and then with $0.5 \mathrm{~N}$ hydrochloric acid, using p-nitrophenol as indicator. The small volumes of the reagents employed make this neutralization a difficult and time-consuming procedure. Experiment showed that it could be simplified by adding to the supernatant obtained after centrifuging a given amount of concentrated ammonia solution sufficient to reduce the acidity to approximately $p H 5$, followed by a fixed volume of a saturated solution of sodium acetate as buffer. The colour is developed in a solution whose final volume is only $0.5 \mathrm{ml}$. so that the micro cells of the Spekker absorptiometer must be ùsed, and hence great care must be taken to ensure consistent readings. The small volumes of serum and reagents required were measured with pipettes of the Ostwald-Folin type, made and calibrated in the laboratory.

\section{Estimation of Serum Iron}

The serum iron is estimated by liberation with hydrochloric acid, and, after the removal of protein, allowing the iron to react with o-phenanthroline in the presence of sodium hydrosulphite. 
Reagents. - The following reagents are required.

6N Hydrochloric Acid.-Constant boiling hydrochloric acid prepared in the usual way in an all-glass apparatus was taken as $6 \mathrm{~N}$.

Trichloracetic Acid $(20 \% w / v)$. - This was prepared from redistilled trichloracetic acid.

$12 N$ Ammonium Hydroxide Solution.-This was prepared from 0.880 ammonia solution by dilution with iron-free water. The strength must be checked from time to time.

Phenanthroline Solution.-This solution was of $0.5 \% \mathrm{w} / \mathrm{v}$ in a $10 \%$ solution of ethyl alcohol in water.

Sodium Hydrosulphite.-This could only be obtained in the technical grade, and could not be readily purified. All specimens we have been able to obtain, even those said to have less than six parts per million of iron, contain as impurity many small black particles, probably carbon. These contain iron, as is shown by the development of colour when treated with o-phenanthroline, and may give rise to errors due to random sampling. They are removed by sifting through a fine sieve. Since sodium hydrosulphite even in the solid state deteriorates on exposure to air, it was found preferable to keep only a small amount in a separate bottle for immediate use. The addition of the very small quantity of the solid was accomplished by means of a glass capillary scoop calibrated by weighing five combined deliveries. A solution of sodium hydrosulphite may be used, providing it is freshly prepared and stabilized with sodium acetate, in which case $0.01 \mathrm{ml}$. of a $3 \%$ solution in $0.1 \mathrm{~N}$ sodium acetate solution is added instead of $0.3 \mathrm{mg}$. of the solid.

Standard Iron Solutions.-Cleaned pure iron wire (100 mg.) was dissolved in $1.2 \mathrm{ml}$. of $6 \mathrm{~N}$ hydrochloric acid, and made up to $1 \mathrm{l}$. with iron-free water. By appropriate dilutions with redistilled water a range of standard solutions containing from $60 \mu \mathrm{g}$. to $260 \mu \mathrm{g}$. iron per $100 \mathrm{ml}$. were obtained.

All glassware was made iron-free by immersion in concentrated hydrochloric acid for two days, then rinsing several times with distilled water, and finally three times with redistilled water. The iron-free water was obtained by redistillation of distilled water in an all-glass apparatus.

Procedure.-To $0.2 \mathrm{ml}$. of serum in a small test-tube is added drop by drop and with shaking $0.1 \mathrm{ml}$. of $6 \mathrm{~N}$ hydrochloric acid. The mixture is allowed to stand for 10 minutes, after which $0.2 \mathrm{ml}$. of $20 \%$ trichloracetic acid solution is added drop by drop and with shaking and allowed to stand a further 10 minutes. After centrifuging at high speed for about 10 minutes $0.37 \mathrm{ml}$. of the clear supernatant is taken into a 2 in. $\times \frac{3}{8}$ in. rimless test-tube calibrated at $0.55 \mathrm{ml}$. To this, $0.05 \mathrm{ml}$. of $12 \mathrm{~N}$ ammonium hydroxide solution is added, followed by $0.05 \mathrm{ml}$. of a saturated solution of sodium acetate. Then approximately $0.01 \mathrm{ml}$. of the phenanthroline solution is added and finally $0.3 \mathrm{mg}$. of solid sodium hydrosulphite. The reagents are mixed well by tapping after the addition of each. Finally the solution is made up to the calibration mark with redistilled water and again mixed. The full colour develops immediately, and may be read after only a few minutes, or, since the colour is quite stable, after standing for an hour or longer. In this investigation a Spekker absorptiometer and $1-\mathrm{cm}$. depth micro cells with the spectral green (Ilford No. 604) filter were used, the readings being made against water. When carrying out a batch of serum-iron estimations together a series of standard iron solutions and a reagent blank were always included. The value of the serum iron may be read off directly on the linear curve obtained by plotting the Spekker readings of the standard iron solutions against the iron content (Fig. 1).

\section{Estimation of Total Iron-binding Capacity of Serum}

In this method iron is added to serum in an amount more than sufficient to saturate the iron-binding $\beta_{1}$ globulin component. The excess is allowed to react with phenanthroline in the presence of sodium hydrosulphite. The addition of hydrochloric acid liberates the iron from the iron-globulin compound but not from the iron-phenanthroline complex, which is precipitated, together with all the protein, by trichloracetic acid. The liberated iron, representing the total iron-binding capacity of the serum, is then estimated as for serum iron.

Reagents.-The only additional reagent required is a solution containing $50 \mu \mathrm{g}$. iron per $\mathrm{ml}$. This is reduced immediately before use by the addition of $20 \mathrm{mg}$. ascorbic acid to $10 \mathrm{ml}$. of iron solution.

Procedure.-To $0.2 \mathrm{ml}$. serum in a small test-tube is added $0.025 \mathrm{ml}$. of the freshly reduced $50 \mu \mathrm{g} . / \mathrm{ml}$. iron solution. Then $0.01 \mathrm{ml}$. of phenanthroline solution is added, followed by $0.3 \mathrm{mg}$. of sodium hydrosulphite. The solution is well mixed by tapping, and, after standing one hour, $0.2 \mathrm{ml}$. of the mixture is removed and added slowly and with shaking to a mixture of $0.15 \mathrm{ml}$. $6 \mathrm{~N}$ hydrochloric acid and $0.1 \mathrm{ml}$. distilled water. This is allowed to stand for 10 minutes, after which $0.3 \mathrm{ml}$. of the $20 \%$ trichloracetic acid is added drop by drop, with shaking. After standing a further 10 minutes the mixture is centrifuged at high speed for 10 minutes or till the supernatant is clear. From this, $0.37 \mathrm{ml}$. is removed and placed in a small test-tube graduated at $0.55 \mathrm{ml}$. The colour is developed as for serum iron by the successive additions of $0.05 \mathrm{ml}$. of $12 \mathrm{~N}$ ammonium hydroxide solution, $0.05 \mathrm{ml}$. saturated sodium acetate solution, approximately $0.01 \mathrm{ml}$. phenanthroline solution, and $0.3 \mathrm{mg}$. sodium hydrosulphite, mixing well after each addition, and finally making up to $0.55 \mathrm{ml}$. The reading is made in the micro cell of the Spekker absorptiometer as before.

Calculation.-The total iron-binding capacity is obtained by reading off the amount of iron on the standard iron graph and multiplying by the factor 1.76.

$$
\begin{aligned}
& \text { Total iron-binding capacity }(\mu \mathrm{g} . / 100 \mathrm{ml} .)=\mathbf{R} \times \frac{0.235}{0.20} \times \frac{0.75}{0.50} \\
&=\mathbf{R} \times 1.76 \\
& \text { where } R=\text { amount of iron read off on the graph }
\end{aligned}
$$




\section{Correlation of Iron Content and Colour Development}

Fig. 1 shows the linear relation between the Spekker readings and iron content between zero

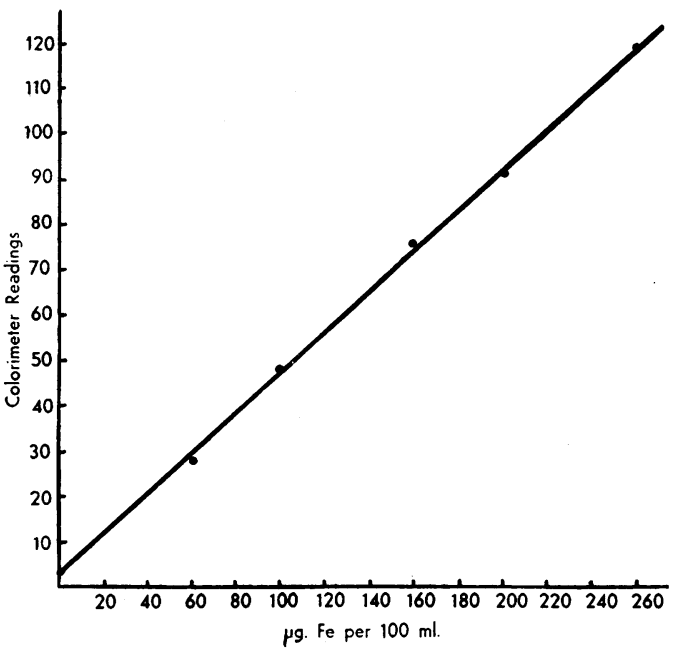

Fig. 1.-Graph of correlation between iron content and colorimeter readings.

and $260 \mu \mathrm{g}$. iron $/ 100 \mathrm{ml}$, a range covering all the readings required for the values of serum iron and iron-binding capacity which have been found.

\section{Accuracy of the Method}

In general, there was no difficulty in obtaining good duplicate results. Replicate estimations of serum iron and total iron-binding capacity on 0.2 $\mathrm{ml}$. amounts of the same serum gave the following results.

\begin{tabular}{|c|c|c|c|c|}
\hline & $\begin{array}{c}\text { Mean } \\
(\mu \mathrm{g} . / 100 \mathrm{ml} .)\end{array}$ & $\begin{array}{c}\text { Range } \\
(\mu \mathrm{g} . / 100 \mathrm{ml} .)\end{array}$ & $\begin{array}{c}\text { Standard } \\
\text { Deviation } \\
(\mu \mathrm{g} . / 100 \mathrm{ml} .)\end{array}$ & $\begin{array}{c}\text { Standard } \\
\text { Error } \\
\text { of Mean } \\
(\mu \mathrm{g} . / 100 \mathrm{ml} .)\end{array}$ \\
\hline Serum iron. & $\begin{array}{c}129 \cdot 6 \\
(5 \text { results })\end{array}$ & $125-135$ & $\pm 3 \cdot 6$ & \pm 1.6 \\
\hline $\begin{array}{l}\text { Total serum } \\
\text { iron-binding } \\
\text { capacity }\end{array}$ & $\begin{array}{c}361 \\
\text { (6 results) }\end{array}$ & $343-369$ & $\pm 9 \cdot 7$ & $\pm 4 \cdot 0$ \\
\hline
\end{tabular}

In order to obtain reproducible results with these very small amounts of iron it is best to work in an atmosphere as free of dust as possible. In our case the conditions were far from ideal, and to reduce contamination all reagents and glassware were kept, and as far as possible all manipulations carried out, under a large perspex cover. The small test-tubes in which precipitation and development of colour were carried out were always kept capped with tin foil except when reagents were added or aliquots removed. Even with all these precautions occasionally high results were obtained outside the limit of experimental error. These can be ascribed either to random sampling of impurity in the sodium hydrosulphite or to random contamination with dust particles containing traces of iron.

\section{Effect of Free Haemoglobin on Serum Iron and Iron-binding Capacity}

The purpose of this investigation was to devise a method applicable to the small amounts of blood obtainable by heel or finger prick in infants and children, and since such specimens of serum would inevitably be somewhat haemolysed it was important to verify the observations of Heilmeyer and Plötner (1937) and Vahlquist (1941) on haemolysed sera. These authors showed that the liberation of iron from haemoglobin by $6 \mathrm{~N}$ hydrochloric acid was too small to affect the serum-iron estimation. Venndt (1940) showed that this liberation was greatly decreased if the serum containing haemoglobin was first saturated with carbon monoxide. Laurell (1947) confirmed this result and concluded that the presence of free haemoglobin in concentrations up to $380 \mathrm{mg}$. \% in serum affected neither the serum-iron estimation nor the serum ironbinding capacity again provided that the serum was first treated with carbon monoxide, although he pointed out that the values for iron-binding capacity tended to be too high with strongly haemolytic sera. The following experiments were performed to verify these observations.

A solution of haemoglobin was prepared by lysing washed red blood corpuscles with water, and sera containing $70 \mathrm{mg}$., $140 \mathrm{mg}$., and $280 \mathrm{mg}$. per $100 \mathrm{ml}$. were obtained by adding suitable amounts of this solution to a specimen of serum free from haemoglobin. These sera were all saturated with pure carbon monoxide. Duplicate estimations of serum iron and iron-binding capacity were carried out on the original serum and the three sera containing varying amounts of free haemoglobin. From the results obtained (Table I) it may be concluded that the presence of haemoglobin in amounts up to $140 \mathrm{mg}$. per $100 \mathrm{ml}$. of serum

TABLE I

ESTIMATION OF SERUM IRON AND IRON-BINDING CAPACITY IN THE PRESENCE OF HbCO

\begin{tabular}{c|c|c}
\hline $\begin{array}{c}\text { Amount of } \mathrm{Hb} \\
\text { in Serum } \\
(\mathrm{mg} . / 100 \mathrm{ml} .)\end{array}$ & $\begin{array}{c}\text { Serum Iron } \\
(\mu \mathrm{g} . / 100 \mathrm{ml})\end{array}$ & $\begin{array}{c}\text { Total Iron- } \\
\text { Binding Capacity } \\
(\mu \mathrm{g} / 100 \mathrm{ml} .)\end{array}$ \\
\hline 0 & 130 & 361 \\
70 & 131 & 375 \\
140 & 129 & 379 \\
280 & 159 & 408 \\
\hline
\end{tabular}


(equivalent to approximately a $1 \%$ haemolysis of the red corpuscles) will not affect the serum iron estimation, providing the haemoglobin is converted to carboxyhaemoglobin. Above this amount the serum iron values tend to be too high. This also applies to the serum iron-binding capacity, within the limits of experimental error. The results therefore confirm those of previous investigators.

\section{Serum Iron and Total Iron-binding Capacity of Serum in Normal Adults}

These were estimated in a group of 40 adults, 20 males and 20 females.

Material.-The subjects were between the ages of 18 and 45 years. No attempt was made to take the specimens of blood under fasting conditions or at set times. Samples of capillary blood were taken from ear or finger, and the serum was separated within an hour of collection. Before estimating serum iron the serum was frozen for 24 hours or longer, as recommended by Laurell (1947). Many of the specimens contained some free haemoglobin, judged by naked-eye examination. All such sera were saturated with pure carbon monoxide before analysis. Any samples showing more than $1 \%$ haemolysis, as estimated by comparison with serum containing known amounts of haemoglobin, were rejected as being unsuitable for estimation.

Haemoglobin was estimated by the alkaline haematin method, using the Spekker absorptiometer.

\section{Experimental Results}

In Table II are shown the results obtained in males and females. They agree well with other published figures, as shown in Table III, which summarizes the results obtained in this and
TABLE II

SERUM IRON AND TOTAL IRON-BINDING CAPACITY IN NORMAL ADULTS

\begin{tabular}{|c|c|c|c|c|c|c|c|c|}
\hline \multicolumn{5}{|c|}{ Males } & \multicolumn{4}{|c|}{ Females } \\
\hline No. & $\begin{array}{c}\text { Serum } \\
\text { Iron } \\
(\mu \mathrm{g} . / \\
100 \mathrm{ml} .\end{array}$ & \begin{tabular}{|c|} 
Total \\
Iron- \\
binding \\
Capa- \\
city \\
$(\mu \mathrm{g} .1$ \\
$100 \mathrm{ml})$. \\
\end{tabular} & $\begin{array}{c}\text { Satura- } \\
\text { tion }\end{array}$ & $\underset{(\mathrm{g} . \%)}{\mathrm{Hb}}$ & $\begin{array}{c}\text { Serum } \\
\text { Iron } \\
(\mu \mathrm{g} \cdot / \\
100 \mathrm{ml} .)\end{array}$ & \begin{tabular}{|c|} 
Total \\
Iron- \\
binding \\
Capa- \\
city \\
$(\mu \mathrm{g} . l$ \\
$100 \mathrm{ml})$.
\end{tabular} & $\underset{\substack{\text { Satura } \\
\text { tion }}}{\%}$ & $\underset{(\mathrm{g} . \%)}{\mathbf{H b}}$ \\
\hline $\begin{array}{r}1 \\
2 \\
3 \\
4 \\
5 \\
6 \\
7 \\
8 \\
9 \\
10 \\
11 \\
12 \\
13 \\
14 \\
15 \\
16 \\
17 \\
18 \\
19 \\
20\end{array}$ & $\begin{array}{r}109 \\
76 \\
142 \\
140 \\
109 \\
133 \\
158 \\
150 \\
140 \\
116 \\
156 \\
132 \\
110 \\
120 \\
108 \\
152 \\
130 \\
132 \\
105 \\
102 \\
\end{array}$ & $\begin{array}{l}387 \\
298 \\
290 \\
298 \\
334 \\
373 \\
312 \\
306 \\
249 \\
249 \\
302 \\
268 \\
327 \\
266 \\
272 \\
274 \\
304 \\
314 \\
378 \\
286\end{array}$ & 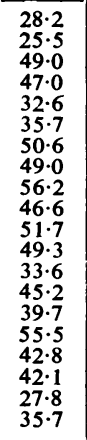 & $\begin{array}{l}14.2 \\
16.3 \\
15.7 \\
15.4 \\
14.5 \\
15.8 \\
14.4 \\
16.0 \\
16.4 \\
15.2 \\
16.9 \\
15.5 \\
15.8 \\
15.4 \\
15.4 \\
14.9 \\
15.8 \\
15.8 \\
16.3\end{array}$ & $\begin{array}{r}110 \\
82 \\
95 \\
173 \\
106 \\
93 \\
90 \\
134 \\
126 \\
122 \\
60 \\
128 \\
88 \\
64 \\
134 \\
88 \\
84 \\
132 \\
107 \\
62\end{array}$ & $\begin{array}{l}335 \\
338 \\
370 \\
338 \\
266 \\
311 \\
386 \\
275 \\
316 \\
393 \\
429 \\
268 \\
274 \\
204 \\
282 \\
328 \\
355 \\
308 \\
341 \\
282\end{array}$ & $\begin{array}{l}32 \cdot 8 \\
24 \cdot 3 \\
25 \cdot 7 \\
51 \cdot 2 \\
39.9 \\
29.9 \\
23 \cdot 3 \\
48 \cdot 7 \\
39.9 \\
31 \cdot 0 \\
14.0 \\
47 \cdot 8 \\
32.1 \\
31.4 \\
47 \cdot 5 \\
26.8 \\
23.7 \\
43.9 \\
31.4 \\
22.0\end{array}$ & $\begin{array}{l}\overline{13.3} \\
13.0 \\
12.1 \\
13.9 \\
15.4 \\
13.2 \\
14.1 \\
12.9 \\
14.4 \\
12.1 \\
14.4 \\
13.9 \\
14.7 \\
14.5 \\
12.7 \\
12.6 \\
13.2 \\
11.1 \\
13.6\end{array}$ \\
\hline Mean & $126 \cdot 0$ & $304 \cdot 3$ & $42 \cdot 2$ & & 103.9 & 320 & $33 \cdot 3$ & \\
\hline Range & $\begin{array}{l}76- \\
158\end{array}$ & $\begin{array}{l}249- \\
387\end{array}$ & $\begin{array}{l}25 \cdot 5- \\
56 \cdot 2\end{array}$ & & $\begin{array}{c}60- \\
173\end{array}$ & $\begin{array}{l}204- \\
429\end{array}$ & $\begin{array}{l}14.0- \\
51 \cdot 2\end{array}$ & \\
\hline S.D. & $\pm 21 \cdot 5$ & $\pm 39 \cdot 8$ & $\pm \overline{9 \cdot 4}$ & & \pm 28.9 & \pm 52.8 & $\pm \overrightarrow{10.4}$ & \\
\hline $\begin{array}{l}\text { S.E } \\
\text { mea }\end{array}$ & $4 \cdot 8$ & $\pm 8 \cdot 9$ & $\pm 2 \cdot 1$ & & \pm 6.5 & \pm 11.8 & $\pm 2 \cdot 3$ & \\
\hline
\end{tabular}

previous investigations of normal adults in which both serum iron and iron-binding capacity have been determined. As might be expected, our results agree best with those of Laurell (1947). There are certain discrepancies between the results obtained by different observers. Most agree that the mean value for serum iron in males is higher than in females, although Cartwright and Wintrobe (1949) found no significant difference. Our results show a higher mean serum iron for males than for

TABLE III

SERUM IRON AND IRON-BINDING CAPACITY IN NORMAL ADULTS

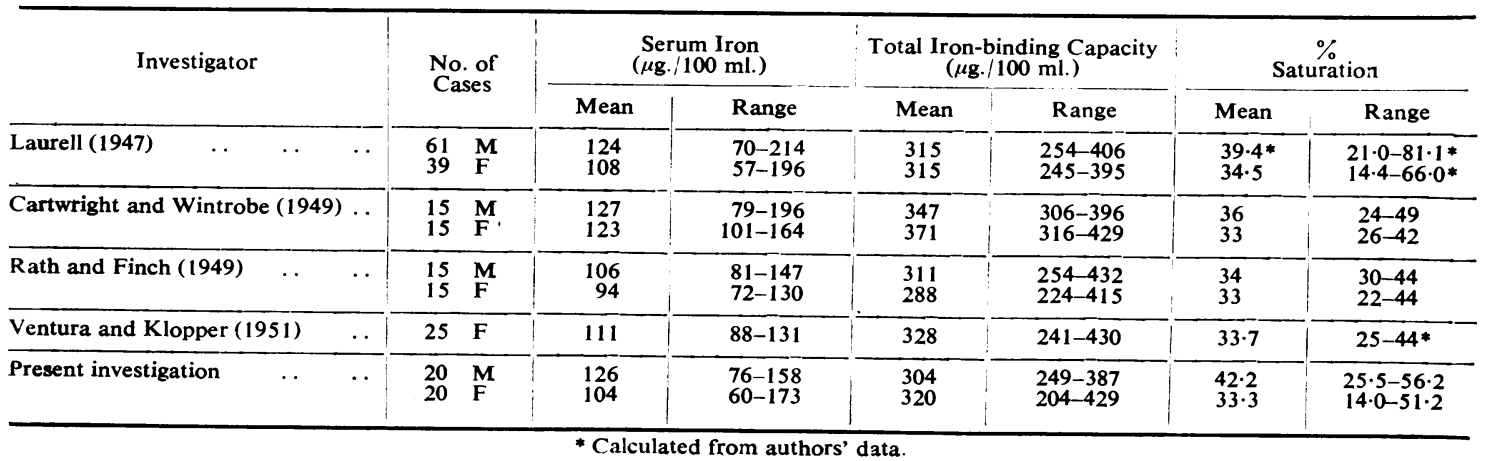


females, which is statistically significant. There is no such clear-cut difference in the case of the total iron-binding capacity. Laurell (1947) could detect none between males and females in this respect, Rath and Finch (1949) found the total iron-binding capacity somewhat higher in males than in females, whereas Cartwright and Wintrobe (1949) found the reverse. Our results agree rather with those of the last, since we also found a higher mean ironbinding capacity in females than in males. In view of these discordant findings it is difficult to estimate the significance of these differences in total iron-binding capacity, especially when the wide spread of results, as well as the relatively small numbers in each group, are considered. In all investigations so far reported the ratio of serum iron to total iron-binding capacity (percentage saturation) is greater for males than for females, but in two series the difference does not appear to be significant. In the present investigation the percentage saturation is significantly greater for males than for females, the difference being $9 \%$, a value larger than that calculated from Laurell's figures, which was only $5 \%$.

\section{Serum Iron and Iron-binding Capacity in Disease}

A number of estimations of serum iron and ironbinding capacity have also been performed in hypochromic anaemia and haemochromatosis, as well as in two cases of transfusion haemosiderosis. The results, which are similar to those obtained by other investigators, are shown in Table IV.

\section{TABLE IV}

SERUM IRON AND IRON-BINDING CAPACITY IN PATHOLOGICAL CONDITIONS

\begin{tabular}{|c|c|c|c|c|c|}
\hline & Sex & $\mid \begin{array}{c}\text { Serum } \\
\text { Iron } \\
(\mu \mathrm{g} \cdot / 100 \mathrm{ml} .)\end{array}$ & $\begin{array}{c}\text { Total } \\
\text { Iron- } \\
\text { Binding } \\
\text { Capacity } \\
(\mu \mathrm{g} . / 100 \mathrm{ml} .)\end{array}$ & $\stackrel{\%}{\text { Saturation }}$ & $\underset{(\mathrm{g} . / 100 \mathrm{ml} .)}{\mathrm{Hb}}$ \\
\hline $\begin{array}{r}1 \\
2 \\
3 \\
4 \\
5 \\
6 \\
7 \\
8 \\
9 \\
10\end{array}$ & $\begin{array}{l}\mathbf{F} \\
\mathbf{F} \\
\mathbf{F} \\
\mathbf{F} \\
\mathbf{F} \\
\mathbf{F} \\
\mathbf{M} \\
\mathbf{M} \\
\mathbf{M} \\
\mathbf{M}\end{array}$ & $\begin{array}{l}\text { Hypochr } \\
20 \\
43 \\
21 \\
39 \\
39 \\
46 \\
21 \\
20 \\
45 \\
37\end{array}$ & \begin{tabular}{|} 
romic Anaemia \\
370 \\
442 \\
540 \\
372 \\
-376 \\
476 \\
382 \\
402 \\
371 \\
375 \\
\end{tabular} & $\begin{array}{r}5.4 \\
9.7 \\
3.9 \\
10.5 \\
10.4 \\
9.7 \\
5.5 \\
5.0 \\
12.2 \\
7.8\end{array}$ & $\begin{array}{r}6 \cdot 8 \\
4 \cdot 9 \\
8 \cdot 0 \\
5 \cdot 5 \\
10 \cdot 2 \\
9 \cdot 5 \\
7 \cdot 3 \\
9 \cdot 3 \\
5.9 \\
5 \cdot 6\end{array}$ \\
\hline \multicolumn{5}{|c|}{ Haem xchromatosis } & $\cdot$ \\
\hline $\begin{array}{l}1 \\
2 \\
3 \\
4 \\
5\end{array}$ & $\begin{array}{l}\mathbf{M} \\
\mathbf{M} \\
\mathbf{M} \\
\mathbf{M}\end{array}$ & $\begin{array}{l}243 \\
240 \\
293 \\
257 \\
255\end{array}$ & $\begin{array}{l}239 \\
251 \\
303 \\
256 \\
249\end{array}$ & $\begin{array}{r}100 \\
96 \\
97 \\
100 \\
100\end{array}$ & \\
\hline \multicolumn{6}{|c|}{ Transfusion Haemosiderosis } \\
\hline $\begin{array}{l}1 \\
2\end{array}$ & $\begin{array}{l}\mathbf{F} \\
\mathbf{F}\end{array}$ & $\begin{array}{l}381 \\
305\end{array}$ & $\begin{array}{l}378 \\
322\end{array}$ & $\begin{array}{r}100 \\
95\end{array}$ & \\
\hline
\end{tabular}

Hypochromic Anaemia.-The results in 10 cases show that the range of serum iron is lower than the normal, while that of the iron-binding capacity falls in the upper limit of the normal range. The percentage saturation is always low, in this series below $12.2 \%$, compared with a mean percentage saturation of $33.3 \%$ for females and $42.2 \%$ for males.

Haemochromatosis. - The results show that in this condition the serum iron is always greater than normal, whilst the iron-binding capacity is within the lower limits of normal. What is of greater significance, however, is that the percentage saturation appears to be always $100 \%$ or nearly so. This may also occur in other conditions, pernicious anaemia, aplastic anaemia (primary refractory anaemia), Mediterranean anaemia, and transfusion haemosiderosis. Haemochromatosis is perhaps not so uncommon as might be supposed, and the results indicate that these estimations afford a relatively easy laboratory test in suspected cases of this disease.

Both cases of transfusion haemosiderosis due to multiple transfusions for aplastic anaemia showed $100 \%$ or nearly $100 \%$ saturation of the iron bind ing capacity.

\section{Summary}

A micro-method for the estimation of serum iron and iron-binding capacity, requiring only 0.2 $\mathrm{ml}$. serum for each, is described.

Using this method, the serum iron and ironbinding capacity in a group of normal adults, 20 males and 20 females, as well as in a group of cases of haemochromatosis and hypochromic anaemia, have been determined.

We wish to thank Dr. M. Lubran and Dr. N. F. Coghill for specimens of sera from patients with haemochromatosis and Drs. Hopkins and Bernstock for those from patients with hypochromic anaemia.

The above forms part of an investigation undertaken by Helen M. Mackay and B. Levin, with the assistance of G. Davies and V. G. Oberholzer, who gratefully acknowledge grants from the Medical Research Council.

\section{REFERENCES}

Budtz-Olsen, O. E. (1951). Journal of Clinical Pathology, 4, 92 Burch, H. B. Lessey, O. A., and Berson, B. Z. (1948) J. biol. Chem., 174, 791.

Cartwright, G. E., and Wintrobe, M. M. (1949). J. clin. Invest., 28, 86.

Heilmeyer, L., and Plötner, K. (1937). Das Serumeisen und die Eisenmangelkrankheit. Jena.

Holmberg, C. G., and Laurell, C.-B. (1945). Acta physiol. scand., 10 , 307.

Laurell, C.-B. (1947). Ibid., 14, Suppl. 46.

Rath, C. E., and Finch, C. A. (1949). J. clin. Invest., $28,79$.

Schade, A. L., and Caroline, L. (1946). Science, 104, 340.

Schade, A. L., and Caroline, L. (1946). Science, 104, 340.

Vahlquist, B. C. (1941). Acta paediat., Uppsala, 28, Suppl. 5.
Venndt, H. (1940). Hoppe-Seyl. Z. phvsiol. Chem., 283, 162.

Venndt, H. (1940). Hoppe-Seyl. Z. phvsiol. Chem., 263, 162.
Ventura, S., and Klopper, A. (1951). J. Obstet. Gynaec. Brit. Emp., 58,173 . 